\title{
PENERAPAN KONSEP GREEN MANAGEMENT DALAM PERSPEKTIF YURIDIS
}

\author{
Oleh : Nina Herlina, S.H., M.H. ${ }^{*}$
}

\begin{abstract}
The implementation of green management by a company will greatly assist in law enforcement, in particular environmental law and will provide a sense of security and a sense of fair society when dealing with environmental issues. The implementation of green management of the juridical side will provide, among others, to encourage the development prospects of business ethics in this case is the aspect of corporate social responsibility to the community and the legal aspects of the role of the community to assist the government in fostering the increased quality of participation itself. For entrepreneurs by implementing green management indirectly prevent environmental pollution not only at the end of the production process, namely waste management but also prevent any waste in every link of the process. Given these actions will indirectly foster proactive behavior to prevent environmental pollution.
\end{abstract}

\begin{abstract}
ABSTRAK
Penerapan green management oleh suatu perusahaan akan sangat membantu dalam penegakan hukum, khususnya hukum lingkungan serta akan memberikan rasa aman dan rasa adil bagi masyarakat bila berhadapan dengan masalah-masalah lingkungan. Penerapan green management dari sisi yuridis akan memberikan prospek antara lain mendorong berkembangnya etika bisnis dalam hal ini adalah aspek tanggung jawab sosial perusahaan kepada masyarakat dan dari sisi aspek hukum peran serta masyarakat justru membantu pemerintah dalam mendorong meningkatnya kualitas peran serta itu sendiri. Sebab pengusaha dengan menerapkan green management secara tidak langsung telah mencegah pencemaran lingkungan tidak hanya pada akhir proses produksi saja, yakni dengan pengelolaan limbah melainkan juga mencegah terjadi limbah pada setiap mata rantai proses tersebut. Dengan adanya tindakan ini secara tidak langsung akan menumbuhkan perilaku proaktif dalam mencegah pencemaran lingkungan.
\end{abstract}

\footnotetext{
${ }^{*}$ Dosen Fakultas Hukum Universitas Galuh
} 


\section{Pendahuluan}

Dalam era perdagangan bebas, maka akan terbentuklah suatu pasar perdagangan yang mendasarkan pada tingginya daya saing atas suatu produk/jasa yang disajikan oleh setiap negara di dunia. Tentunya, hal ini akan mendorong juga kebijakan perdagangan pemerintah kita yang mengarah pada peningkatan daya saing yang tinggi atas produk/jasa tersebut. Oleh karena itu konsekuensi ini menjadikan perusahaan nasional kita akan menghadapi medan persaingan yang mau tidak mau menjadikan dirinya harus siap untuk berkompetisi dan meningkatkan kemampuannya untuk berkompetisi, sebab mereka akan selalu menghadapi persaingan antara lain guna menembus pasar domestik negara asing ia harus bersaing dengan para pesaing asing dalam mendapatkan pelanggannya disamping bersaing dengan sesama pengusaha nasional ia juga harus bersaing dengan para pesaing yang datang dari luar negeri guna mencari pelanggan dan untuk menguasai pasar domestik yang semakin terbuka (Erwin, $2008:$ 47).

Dalam dunia yang terintegrasi, yang seolah tanpa batas-batas fisik (the borderless world) memaksa semua pihak untuk siap bersaing dan hanya perusahaan yang mencapai efisiensi saja yang mampu memenangkan persaingan, sehingga konsekuensinya hanya pelaku-pelaku ekonomi yang paling efisien yang akan bertahan dan berkembang, kompetitor yang tidak efisien akan segera ditinggalkan pelanggannya dan kemudian meninggalkan pasar (Prasentiantono ,1996:1).

Salah satu bentuk efisiensi yang telah menjadi isu global pada dewasa ini adalah ecoefisiensi yaitu upaya yang mengaitkan antara kinerja suatu Perusahaan dengan lingkungan hidup. Hal ini berarti bahwa dalam era perdagangan bebas ini ada suatu tuntutan bahwa terhadap kinerja suatu perusahaan perlu dilakukan terobosan dalam manajemennya, yakni perlu melakukan suatu manajemen yang mengintervensikan masalah lingkungan hidup sebagai bagian dari aktivitas perusahaan/perdagangannya. Manajemen yang demikian ini kemudian dikenal dengan istilah Green management (Suyatno, 1995:32).

Bagi Indonesia yang politik pembangunannya menekan pada pertumbuhan ekonomi yang tinggi, tertunya peran serta perusahaan sebagai komponen pelaku ekonomi memiliki peran yang strategis bagi upaya itu, sebab 
perusahaan-perusahaan itu akan menjadi ujung tombak bagi perekonomian negara dalam memasuki perdagangan bebas, khususnya dalam menghadapi produk-produk perusahaan negara lain yang akan begitu bebasnya masuk ke dalam pasar Indonesia. Oleh karena itu, persoalan lingkungan hidup telah menjadi bagian yang integral dari perdagangan itu sendiri dalam arti bahwa perusahaan memang memiliki kemampuan untuk berperan serta dalam mencegahnya kerusakan lingkungan hidup, di mana melalui manajemennya perusahaan dapat mengemas masalah lingkungan sedemikian rupa sehingga selain dapat sebagai alat pertanggungjawaban moral dalam mencegah kerusakan lingkungan hidup juga sebagai alat peluang bisnis. Maka untuk itu, mau tidak mau perusahaan di Indonesia memang harus mempersiapkan diri dalam mengadopsi green Management tersebut dalam setiap aktivitasnya. (Baiquni, 2002: 73)

Berdasarkan urian tersebut, dalam tulisan ini akan dibahas mengenai bagaimanakah penerapan konsep green management dalam perspektif yuridis.

\section{Pembahasan}

A. Konsep Green Management

Konsep green management memang memiliki pengertian yang sedikit berbeda dengan konsep manajemen konvensional. Konsep green management ini pada dasarnya dikembangkan dari konsep yang ingin menyimpangi paradigma ekonomi klasik atas pengkategorian barang di dunia. Aliran ekonomi klasik telah mengkategorikan barang di dunia menjadi dua bagian besar yakni barang bebas dan barang yang bernilai ekonomi. Terhadap barang bebas seperti misalnya samudera, sungai, hutan, ikan dilaut, ataupun udara memberikan kebebasan kepada setiap orang bebas untuk mengeksploitasinya karena memang untuk itu tidak ada hak perorangan di atasnya (milik bersama), berbeda dengan barang ekonomis di mana barang-barang tersebut tidak bisa diperlakukan demikian. Pengkategorian adanya barang bebas ini ternyata dalam perkembangannya justru sangat merugikan kepentingan ekonomi itu sendiri, sebab terhadap barang bebas (yang pada umumnya adalam alam lingkungan) justru dari waktu ke waktu telah terjadi eksploitasi berlebihan yang cenderung merusaknya. 
Dalam setiap aktifitas perusahaan faktor lingkungan yang semula dianggap sebagai barang bebas dan merupakan external cost (di luar struktur biaya perusahaan) harus diperhitungkan ke dalam faktor biaya produksi dari setiap aktifitas perusahaan. Dengan dimasukkannya faktor lingkungan ke dalam struktur biaya maka kerusakan lingkungan akan semakin dapat ditekan dan hal ini berarti secara tak langsung juga menyelamatkan sumber daya alam sebagai modal kegiatan ekonomi itu sendiri.

Untuk menuju ke arah itu tentu diperlukan suatu upaya/mekanisme guna merealisasikannya secara tegas, maka untuk itu kemudian digunakanlah mekanisme manajemen yang dalam pelaksanaannya memasukkan faktor lingkungan ke dalam bagiannya dan manajemen ini kemudian dikenal dengan istilah Green management (Suyatno, 1995: 33-34).

B. Faktor Yang Mempengaruhi Perlunya Segera Diterapkan Green Management Dalam Perusahaan Di Indonesia

Dalam konteks perdagangan bebas ini, yang mulai memasukkan masalah lingkungan hidup sebagai bagian integral perdagangan suatu negara, dan secara global ada 2 (dua) faktor penting yang sangat mempengaruhi perlunya diterapkan manajemen tersebut dalam Perusahaan di Indonesia. Faktor-faktor itu antara lain adalah;

1. Faktor-Faktor Yuridis

Dari sisi yuridis ini memang tidak ada aturan yang secara khusus mengatur masalah perdagangan dan lingkungan dalam aturan tersendiri namun, kita dapat melihat bahwa ada beberapa aturan-aturan yang ditunjukan bagi dunia perdagangan tetapi di dalamnya mengandung ketentuan yang berkaitan dengan masalah lingkungan hidup. Hal itu antara lain dapat kita lihat pada:

a. Final Act of the Uruguay Round, Article XX GATT tentang Exception yang disusun pada tahun 1947, yang isinya antara lain:

1) Necessary to protect public moral;

2) Necessary to protect human, animal or plan, life or health;

3) ......"

Article XX ini kemudian disempurnakan lagi pada Tokyo Round 1979 dan menjadi Agreement on Technical Barrier to Trade 
(Standards code), yang isi di dalamnya berisi konsensus antara lain pertama perlunya penurunan hambatan tarif dan kedua adalah diwajibkannya standarisasi internasional produk dari aspek kesehatan dan pelestarian lingkungan hidup (Kusumadara, 1995:444 ; Aryanto, 1995:6).

Dengan adanya ketentuan ini GATT/WTO telah mengakui keberadaan faktor lingkungan sebagai bagian dari dunia perdagangan dan bahkan lebih jauh untuk merealisasi Agreement tersebut diatas GATTWTO telah mengakui ISO (International Organization for Standardization) sebagai lembaga dunia yang memiliki kualifikasi merumuskan pola standarisasi produk-produk perdagangan yang tidak merusak lingkungan.

b. Pada Deklarasi Rio dan Agenda 21 dari KTT Bumi 1992 yang telah berlangsung di Rio de Janeiro pada tahun 1992. Dalam kesepakatan internasional tersebut, untuk Deklarasi Rio telah dihasilkan 27 Prinsip, salah satu prinsip itu, yakni Prinsip 12 menyangkut bidang perdagangan yang antara lain menyatakan:

1) Tidak dibenarkannya penggunaan aspek lingkungan sebagai hambatan terselubung dalam perdagangan internasional;

2) Tindakan mengatasi masalah lingkungan yang bersifat antarwilayah dan global harus didasarkan kepada konsensus internasional;

3) Kebijakan perlindungan lingkungan yang dikaitkan dengan perdagangan harus didasarkan kepada azas Nondiskriminasi, Transparansi dan memperhatikan .

Sedang pada Agenda 21 yang merupakan Agenda kerja dari KTT Bumi tersebut tercetus rencana kerja untuk mewujudkan perekonomian internasional yang mampu menciptakan iklim kondusif untuk :

1) Mendorong pembangunan berkelanjutan melalui perdagangan, serta

2) Mengusahakan agar perdagangan dan lingkungan saling mendukung satu sama lainnya (Kusumadara, 1995:447) 
c. Pada ketentuan nasional Negara kita sendiri yakni, ada UndangUndang Nomor 32 Tahun 2009 tentang Perlindungan dan Pengelolaan Lingkungan Hidup Pasal 67 Undang-Undang Nomor 32 Tahun 2009 tentang Perlindungan dan Pengelolaan Lingkungan Hidup, dijelaskan bahwa setiap orang berkewajiban memelihara kelestarian fungsi lingkungan hidup serta mengendalikan pencemaran dan/atau kerusakan lingkungan hidup. Dengan adanya kewajiban bahwa semua bidang usaha wajib memelihara lingkungan dan kewajiban tersebut merupakan salah satu syarat bagi pemberian izin usaha maka mau tidak mau akan menjadikan para pengusaha terikat dalam tindakan pelestarian kemampuan lingkungan hidup untuk menunjang pembangunan yang berkesinambungan.

d. Peraturan Pemerintah Republik Indonesia Nomor 107 Tahun 2015 Tentang Izin Usaha Industri Pasal 7 huruf b, dijelaskan bahwa perusahaan industri wajib menjamin keamanan dan keselamatan alat, proses, hasil produksi, penyimpanan serta pengangkutan. Sedangkan dalam Pasal 23 di mana pasal tersebut menentukan bahwa perusahaan industry dan perluasannya berpengaruh terhadap lingkungan hidup wajib melakukan perubahan terhadap dokumen upaya pengelolaan lingkungan hidup dan upaya pemantauan lingkungan hidup sesuai dengan ketentuan peraturan.

e. Adanya ketentuan Peraturan Pemerintah Republik Indonesia Nomor 27 Tahun 1999 Tentang Analisis Mengenai Dampak Lingkungan Pasal 1 butir 2 Jo. Pasal 2 Ayat (1). Pasal 1 butir 2 Peraturan Pemerintah Republik Indonesia Nomor 27 Tahun 2012 Tentang Izin Lingkungan menyebutkan bahwa Analisis mengenai dampak lingkungan adalah kajian mengenai dampak penting suatu Usaha dan/atau Kegiatan yang direncanakan pada lingkungan hidup yang diperlukan bagi proses pengambilan keputusan tentang penyelenggaraan Usaha dan/atau Kegiatan.

Usaha atau kegiatan yang diperkirakan mempunyai dampak penting terhadap lingkungan hidup meliputi :

a. Pengubahan bentuk lahan dan bentang alam; 
b. Eksploitasi sumberdaya alam baik yang terbaharuhi maupun yang tak terbaharuhi;

c. Proses dan kegiatan yang secara potensial dapat menimbulkan pemborosan, kerusakan, dan kemerosotan sumber daya alam dalam pemanfaatannya;

d. Proses dan kegiatan yang hasilnya dapat mempengaruhi lingkungan sosial dan budaya;

e. Proses dan kegiatan yang hasilnya dapat mempengaruhi pelestarian kawasan konservasi sumber daya alam dan atau perlindungan cagar budaya;

f. Introduksi jenis tumbuh-tumbuhan, jenis hewan, dan jasad renik;

g. Pembuatan dan penggunaan bahan hayati dan non hayati;

h. Penerapan teknologi yang diperkirakan mempunyai potensi besar untuk mempengaruhi lingkungan;

i. Kegiatan yang mempunyai resiko tinggi, dan mempengaruhi pertahanan negara.

Berdasarkan gambaran beberapa dasar hukum diatas maka bagi perusahaan di Indonesia adalah cukup alasan untuk segera menerapkan Green Management dalam melakukan usahanya.

2. Faktor-Faktor Nonyuridis yang mempengaruhi Perlunya Penerapan Green Management

Dari sisi nonyuridis ada beberapa hal yang perlu dipertimbangkan dalam penerapan green management, hal itu adalah adanya perubahanperubahan yang terjadi di masyarakat yang berkaitan dengan masalah lingkungan hidup, sebab dengan semakin mengglobalnya masalah lingkungan hidup jika perubahan-perubahan itu tidak dicermati dan tidak segera diantisipasi sedikit banyak akan mempengaruhi jalannya aktivitas perusahaan di masyarakat. Perubahan-perubahan yang terjadi di masyarakat itu antara lain adalah:

a. adanya gejala yang berkembang dalam perdagangan dunia dewasa ini di mana dalam persaingan dagang yang semakin ketat masalahmasalah lingkungan hidup tampaknya telah dijadikan isu politik yang bermotif dagang, maksudnya bahwa masalah-masalah lingkungan 
telah dijadikan alat politik untuk menghambat perdagangan internasional/perekonomian negara lain (Nogareda, 2006 : 62). Fenomena diatas sesuai benar dengan apa yang disinyalir Erman Rajagukguk, yang mengemukakan bahwa dalam perkembangan perdagangan dunia dewasa ini suatu negara dalam perdagangan internasionalnya harus pula memperhatikan hal-hal yang telah menjadi isu politik dagang, isu-isu itu antara lain munculnya kasuskasus lingkungan, Hak Asasi Manusia, maupun tentang Hak Milik Intelektual (1995:28).

b. Dengan semakin tingginya kesadaran masyarakat dunia terhadap kelestarian lingkungan, munculah kemudian tekanan-tekanan (tuntutan-tuntutan masyarakat internasional) kepada para pelaku bisnis dan pihak perbankan agar di dalam kegiatannya selalu mengkaitkan dengan masalah lingkungan. Tekanan ini kemudian dalam perkembangannya terformulasikan ke dalam Ecolabelling dan Kredit Bank Berwawasan Lingkungan. Ecolabelling pada dasarnya adalah alat untuk penataan, dan menjadi piranti green management karena ecolabelling diwujudkan dalam pemberian label/sertifikat yang didasarkan pada kriteria environmental performance pada setiap produk perusahaan (Salim, 1995:15). Menurut hemat penulis secara lebih luas ecolabelling adalah tuntutan pasar yang menuntut keberanian dan kejujuran pengusaha atas produknya. Sebab pada dasarnya ecolabelling merupakan suatu bentuk informasi pengusaha kepada masyarakat untuk menunjukkan bahwa produk mereka adalah ramah lingkungan dan secara tidak langsung juga menginsyaratkan bahwa kekeliruan atas informasi ini pengusaha yang bersangkutan sanggup untuk mempertanggung jawabkannya. Bentuk kesanggupan inilah sebetulnya yang diharapkan masyarakat karena dengan adanya ini masyarakat merasa telah memperoleh garansi atas penggunaan produk tersebut.

Sedang mengenai Kredit Bank Berwawasan Lingkungan ini dikembangkan dari tuntutan bahwa pemberian bantuan keuangan kepada pengusaha dapat dijadikan sebagai alat pengendali pencemaran lingkungan. Kalau dicermati bahwa pencemaran 
lingkungan yang disebabkan oleh kegiatan usaha atau industri tadi biasanya memperoleh modal dari kredit bank (Hamrat, 2007). Dengan demikian, adanya pengembangan konsep ini secara tidak langsung memberikan tanggung jawab yang semakin besar kepada Bank agar secara ketat memperhitungkan bantuan kredit yang diberikan, bank jangan asal melihat bahwa pengusaha yang diberi bantuan mampu memberikan barang jaminan yang besar, yang apabila nanti menghadapi kendala dalam pengembaliannya barang jaminan tersebut dapat menutupinya. Sementara karena terlalu terfokus pada besarnya jaminan yang diberikan, bank menjadi terlena dan begitu mudahnya melepaskan kredit, sehingga dampak dari perbuatan itu mengakibatkan lingkungan terancam. Dengan semakin berkembangnya hukum lingkungan di dunia dan khususnya Indonesia pada dewasa ini, maka tidak akan menutup kemungkinan bahwa Bank dapat pula dituntut sebagai pihak yang turut tergugat dalam kasus pencemaran/perusakan lingkungan karena hanya teledor dalam memberikan kredit.

c. Terhadap kualitas produk suatu barang yang dihasilkan terdapat tuntutan masyarakat internasional agar dilakukan standarisasi manajemen lingkungan. Standard ini adalah standarisasi yang berkaitan dengan manajemen lingkungan yang dikeluarkan oleh ISO (Internasional Organization for Standarization), yakni yang dikenal dengan ISO 14001.

ISO 14000 terdiri dari enam sub komisi yang menangani enam bidang pekerjaan, yaitu mencakup:

1. Sistem pengelolaan lingkungan;

2. Investigasi dan auditing yang berkaitan dengan lingkungan;

3. Pelabelan produk yang ramah lingkungan (ekolabel);

4. Evaluasi untuk kinerja lingkungan;

5. Pengkajian siklus hidup;

6. Pendefinisian. (Brian, 1996 ; 143)

Standar Sistem Manajemen yang dikeluarkan oleh ISO menerapkan siklus PLAN-DO-CHECK-ACTION (PDCA) dan peningkatan berkelanjutan. Versi sebelumnya baik 1996 dan 2004 
fokus terhadap implementasi pemenuhan peraturan perundangan dan persyaratan lain dengan tujuan untuk mencegah pencemaran lingkungan. Di dalam versi 2015 ini, diharapkan dapat lebih menjelaskan secara detail mengenai isu-isu lingkungan yang terjadi saat ini dan yang akan datang dan menyelaraskan dengan sepuluh struktur "Annex SL"

Ekspektasi organisasi telah diperluas untuk berkomitmen untuk inisiatif proaktif untuk melindungi lingkungan dari bahaya dan degradasi, konsisten dengan konteks organisasi. Teks revisi tidak mendefinisikan 'melindungi lingkungan' tapi mencatat bahwa itu dapat mencakup pencegahan polusi, berkelanjutan penggunaan sumber daya, mitigasi dan adaptasi perubahan iklim, perlindungan keanekaragaman hayati dan ekosistem, dll.

Ada pergeseran penekanan terkait dengan perbaikan terusmenerus untuk meningkatkan kinerja lingkungan yang konsisten dengan komitmen kebijakan organisasi dalam mengurangi emisi, limbah dan limbah ke tingkat yang ditetapkan oleh organisasi.

Selain kebutuhan saat ini untuk mengelola aspek lingkungan yang terkait dengan barang/jasa yang dibeli, organisasi akan perlu untuk melakukan kontrol mereka terhadap dampak lingkungan yang terkait dengan penggunaan produk dan pemakaian akhir atau pembuangan produk yang digunakan.

Pengendalian tambahan terhadap hal di atas diperlukan oleh semua perusahaan/organisasi yang baru akan menerapkan sistem manajemen lingkungan ini atau terjadi penambahan pengendalian operasional dari perusahaan/organisasi yang sudah menerapkannya.

d. Adanya upaya untuk mensosialisasikan konsep perhitungan Produk Domestik Bruto (PDB) yang baru yang dikenal dengan Green Gross Domestic Product (GDP). Dalam konsep ini penghitungan pertumbuhan ekonomi dikaitkan dengan unsur sumber daya alam.

Bila mengingat pentingnya pelestarian sumber daya alam, memang sudah seharusnya Indonesia perlu memasukkan faktor penyusutan sumber daya strategisnya seperti pertambangan, tanah, dan air ke dalam kalkulasi laju pertumbuhan PDB. Sebab selama ini 
kalau laju depresiasi sumber daya alam dan polusi turut diperhitungkan, maka rata-rata laju pertumbuhan PDB Indonesia sejak tahun 1971-1984 hanya sekitar 4,0\% bukan 7,1\% seperti yang dipahami selama ini (Soemawoto, 2000:6).

Memang selama ini hanya modal buatan manusia seperti gedung dan peralatannya saja yang diperhitungkan biaya penyusutannya, tetapi sayangnya logika itu tidak diberlakukan untuk alam. Alam tidak mengenal dana penyusutan, sehingga tidak disediakan dana untuk mensubsitusi kerusakan alam, lantas apa yang akan bisa kita wariskan kepada generasi mendatang kalau sumber daya alam yang ada rusak hanya karena melulu untuk kepentingan ekonomi.

Lebih jauh GDP ini mulai diterapkan maka akan diketahui negara mana yang meronggong lingkungan dan secara politis hal itu tentunya akan mengancam kredibilitas pemerintah di dunia internasional, terutama bila terjadi sanksi-sanksi internasional yang dikaitkan dengan lingkungan, sehingga hal ini tentunya akan menghambat perekonomian Indonesia.

e. Adanya terobosan baru dari pemerintah dalam hal pengendalian dampak lingkungan, yakni adanya penerapan PROPER (Program Penilaian Peringkat Kinerja Perusahaan) dan Audit Lingkungan.

Sedang mengenai Audit Lingkungan adalah suatu alat manajemen yang meliputi evaluasi secara sistematik terdokumentasi periodik dan objektif tentang bagaimana suatu kinerja organisasi, sistem manajemen dan peralatannya terhadap pelaksanaan upaya pengendalian dampak lingkungan.

Dalam audit lingkungan memberikan hak kepada pemerintah untuk melakukan pemeriksaan secara rutin pada suatu usaha/kegiatan, pemerintah juga berhak melakukan pemeriksaan terhadap suatu kegiatan yang dicurigai sebagai kelalaian, penghindaran kewajiban dan pelanggaran terhadap pentaatan hukum dan peraturan, dan hak pemerintah untuk memperoleh informasi khusus sebagai dasar penentuan peringkat kinerja. Dengan demikian, bila kita melihat semakin mengglobalnya sikap 
masyarakat dunia yang semakin kritis terhadap pelestarian lingkungan maka mau tidak mau perusahaan kita memang harus memperhitungkan dan mensikapi sejak dini perubahan-perubahan yang terjadi dalam masyarakat itu. Kita merupakan bagian dari anggota masyarakat dunia yang semakin tinggi kesadaran lingkungannya, maka setiap langkah usaha di bidang lingkungan hidup pasti akan selalu disorot oleh masyarakat dunia. Oleh karena itu, penerapan Green management bagi perusahaan kita setidaktidaknya merupakan terobosan langkah yang tepat. (Keraf, 2014 :59)

Berdasarkan uraian di atas bahwa dari sisi yuridis penerapan green management oleh suatu perusahaan kalau kita analisis akan sangat membantu dalam penegakan hukum, khususnya hukum lingkungan serta akan memberikan rasa aman dan rasa adil bagi masyarakat bila berhadapan dengan masalah-masalah lingkungan. Sebab kalau diprediksi penerapan green management dari sisi yuridis akan memberikan prospek antara lain :

a. mendorong berkembangnya etika bisnis dalam hal ini adalah aspek tanggung jawab sosial perusahaan kepada masyarakat. Dalam kasuskasus lingkungan di negara kita persoalan tanggung jawab sosial perusahaan terhadap lingkungan hidup adalah persoalan yang penting dan utama untuk dikaji, hal ini bila dikaitkan dengan adanya dampak pencemaran lingkungan.

Selama ini dalam kasus-kasus lingkungan di Indonesia permasalahan pencemaran lingkungan yang ditimbulkan oleh suatu perusahaan industri seringkali merugikan masyarakat. Kerugian yang paling menonjol adalah rusaknya lingkungan milik masyarakat dan celakanya dari kerugian itu secara tidak langsung berlanjut pada keadaan di mana sebagian masyarakat harus ikut pula menanggung biaya pemulihan pencemaran tersebut, padalah belum tentu mereka adalah pengguna produk dari perusahaan yang mencemari lingkungan itu. (Sugandy, $2007:$ 113)

Green management memiliki prospek ke arah itu (perwujudan tanggung jawab sosial), hal ini karena green management juga memiliki prospek efisiensi seperti yang telah diuraikan sebelumnya, dengan adanya efisiensi berarti ada penghematan biaya perusahaan yang 
sebelumnya tidak perlu dikeluarkan dan dengan penghematan biaya itu sebagian bisa dialokasikan guna mengelola tanggung jawab sosial. Oleh karena itu, dengan menerapkan green management ini setidak-tidaknya sorotan terhadap kurangnya perusahaan memperhatikan aspek tanggung jawab sosialnya sedikit demi sedikit dapat dikikis.

b. persoalan menarik yang juga berkaitan erat dengan prospek penerapan green management adalah persoalan lingkungan hidup di Indonesia yang selalu berpotensi memunculkan gejolak sosial masyarakat. Menariknya persoalan ini adalah karena berkait erat dengan karekteristik masyarakat Indonesia yang bersifat agraris, di mana kecenderungan gejolak sosial itu justru tidak hanya terbatas pada suasana keresahan masyarakat, protes, ataupun unjuk rasa saja, ataupun boikot produk seperti masyarakat industri pada umumnya tetapi juga telah mengarah pada sikap eigen richting yang berupa perusakan, pembakaran, ataupun bentrokan fisik yang membahayakan jiwa dan benda orang lain. Kalau hal-hal itu sejak dini tidak segera diantisipasi tentu akan dapat mengganggu stabilitas keamanan yang diperlukan bagi pembangunan. Oleh karena itu, pada sisi ini green management memiliki prospek dalam memperkecil/meredam gejolak sosial masyarakat dan kerawanan yang muncul ditengah-tengah masyarakat dari upaya-upaya perbuatan yang bersifat eigen richting yang mengganggu stabilitas keamanan tersebut.

c. Sesuai dengan ketentuan dalam Pasal 65 ayat (4) Undang-Undang Nomor 32 Tahun 2009 tentang Perlindungan dan Pengelolaan Lingkungan Hidup bahwa setiap orang memiliki hak dan kewajiban untuk berperan serta dalam pengelolaan lingkungan hidup, maka dengan adanya penerapan green management ini dari sisi aspek hukum peran serta masyarakat justru membantu pemerintah dalam mendorong meningkatnya kualitas peran serta itu sendiri. Sebab pengusaha dengan menerapkan green management secara tidak langsung telah mencegah pencemaran lingkungan tidak hanya pada akhir proses produksi saja, yakni dengan pengelolaan limbah melainkan juga mencegah terjadi limbah pada setiap mata rantai proses tersebut. Dengan adanya tindakan ini secara tidak langsung akan menumbuhkan perilaku proaktif dalam mencegah pencemaran lingkungan yakni tidak menunggu sampai 
dipaksa oleh pemerintah dengan peraturan tertentu, melainkan telah mengatur dirinya sendiri.

d. Sehubungan dengan penerapan Audit Lingkungan penerapan green management juga akan memiliki prospek dalam mendorong pengembangan ilmu hukum khususnya mendorong bergesernya persepsi orang terhadap kejahatan korporasi lingkungan. Selama ini menurut pengamatan penulis anggapan yang terpola di masyarakat adalah bahwa kejahatan korporasi dalam bidang lingkungan hidup hanyalah masalah-masalah pencemaran/perusakan lingkungan yang secara nyata/fisik tampak di lapangan, sedang masalah-masalah lingkungan yang tidak nyata/non fisik (intangible environment), yakni masalah yang berupa kekeliruan ataupun kelalaian (bahkan bisa disengajaan) di dalam manajemen tidak dianggap sebagai suatu bentuk kejahatan korporasi (Negara, 1996:6).

Anggapan tersebut muncul pada dasarnya karena sulitnya masyarakat untuk dapat mengetahui manajemen suatu perusahaan apakah dia menerapkan green management atau tidak. Sebab selama ini ada suatu anggapan yang terpola bahwa masalah manajemen perusahaan adalah menyangkut masalah teknis intern perusahaan yang tidak dapat dicampuri oleh pihak lain, sehingga setiap kekeliruan ataupun pengabaiannya adalah urusan intern perusahaan itu sendiri yang tabu untuk dicampuri pihak lain. Dengan diterapkannya audit lingkungan anggapan itu kini sudah terkikis, karena dengan audit lingkungan akan semakin memberikan kesempatan kepada masyarakat (dalam hal ini melalui pemerintah) untuk memeriksa/mengetahui apakah suatu perusahaan di dalam manajemennya telah melakukan green management atau mengabaikan sama sekali, kalau ternyata perusahaan itu mengabaikan maka secara cepat masyarakatpun sudah bisa menduga bahwa pencemaran/kerusakan lingkungan pasti akan terjadi. Oleh karena itu, sebenarnya pencemaran lingkungan sudah dapat ditanggulangi sejak awal dari manajemennya, sehingga apabila melakukan pengabaian green management dapatlah dianggap sebagai suatu bentuk kejahatan korporasi. Dengan demikian, anggapan/persepsi masyarakat terhadap kejahatan korporasi lingkungan hanyalah hal-hal 
yang tampak di permukaan saja, sedangkan kegiatan-kegiatan yang selama ini tidak tampak di lapangan karena merupakan proses yang berlangsung secara intern pada tubuh korporasi itu sendiri yang (justru juga tidak banyak diketahui masyarakat) dianggap bukan suatu bentuk kejahatan. Sehingga dengan demikian adanya penerapan green management secara tidak langsung justru memberikan prospek dalam pengembangan ilmu hukum itu sendiri.

\section{Kesimpulan}

Isu lingkungan dalam era perdagangan bebas ini akan berlangsung lama dan menjadi isu sentral, sehingga untuk mengatasinya perlu disusun suatu manajemen agar tidak mengganggu profitabilitas dan pertumbuhan perusahaan. Pemanfaatan Green Management sebagai suatu bentuk manajemen yang menginternalkan faktor lingkungan dalam setiap kegiatan perusahaan adalah merupakan salah satu sarana yang tepat dalam era perdagangan bebas ini, sebab secara yuridis dapat memberikan prospek antara lain mendorong berkembangnya rasa tanggung jawab sosial perusahaan, meredam gejolak sosial masyarakat yang mengarah pada eigen eichting, mendorong kualitas aspek hukum peran serta masyarakat terhadap lingkungan. 


\section{Daftar Pustaka}

Baiquni, M. dan Susilawardani. Pem-bangunan yang Tidak Berkelanjutan Refleksi Kritis Pembangunan Indonesia. Yogya-karta:Transmedia Global Wacana, 2002;

Brian Rothery, Sistem Manajemen Lingkungan ISO 14000, PT.Pustaka Binaman Pressindo, Jakarta, 1996;

Erwin, Muhamad, Hukum Lingkungan Dalam System Kebijaksanaan Pembangunan Lingkungan Hidup, Refika Aditama, Bandung, 2008;

Hamid Hamrat dan Bambang Pramudyanto, Pengawasan Industri Dalam Pengendalian Pencemaran Lingkungan, Edisi I, Granit, Jakarta, 2007;

Keraf A. Sonny, Krisis dan Bencana Lingkungan Hidup Global. cet-5. Kanisius. Yogyakarta, 2014;

Kusumadara, Afifah. "Perlindungan Lingkungan Hidup dalam Perdagangan Internasional". Hukum dan Pembangunan, 1995;

Negara D. Purnawan, Perusahaan yang Abaikan Lingkungan Lakukan Kejahatan Korporasi”. Bisnis Indonesia, 1996;

Nogareda \& Ziegler, Green Management. Balai pustaka Jakarta, 2006;

Prasentiantono, A. Tony. "Agenda Nonekonomi dalam Perekonomian Indonesia pada Era Liberalisasi Perdagangan”,1996;

Rajagukguk, Erman. Hukum Investasi Jilid I. Jakarta: FH-UI, 1995;

Salim, Emil Ecolabelling dan Dampaknya dalam Kegiatan Bisnis (dalam Ecolabelling dan Kecenderungan Lingkungan Hidup Global). Jakarta : PT Bina Rena Pariwara, 1995;

Soemarwoto Otto, Ekoefisiensi: Strategi Peningkatan Daya Saing di Pasar Global (dalam Ecolabelling dan Kecenderungan Lingkungan Hidup Global). Jakarta: PT. Bina Rena Pariwara, 2000;

Sugandy, Aca dan Rustam Hakim, Prinsip Dasar Kebijakan Pembangunan Berkelanjutan Berwawasan Lingkungan. Bumi Aksara. Jakarta, 2007;

Suyatno, Bogy dkk. "Green Management: Strategi Manajemen yang Berwawasan Lingkungan". Minieconomica FE-UI , 1995;

\section{Sumber Perundang-undangan :}

Undang-Undang Republik Indonesia Nomor 32 Tahun 2009 Tentang Perlindungan dan Pengelolaan Lingkungan Hidup; 
Peraturan Pemerintah Republik Indonesia Nomor 27 Tahun 1999 Tentang Analisis Mengenai Dampak Lingkungan;

Peraturan Pemerintah Republik Indonesia Nomor 27 Tahun 2012 Tentang Izin Lingkungan;

Peraturan Pemerintah Republik Indonesia Nomor 107 Tahun 2015 Tentang Izin Usaha Industri. 